\title{
Whether aortic valve repairs are a reasonable substitute for replacement in children? EXPERT REVIEW
}

\author{
Abdurakhmanov Z. M., Varbanets S.V., Yemets I. N. \\ GI "Scientific and Practical Medical Center of Pediatric Cardiology and Cardiac Surgery \\ of the Ministry of Health of Ukraine" (Kyiv)
}

\begin{abstract}
Literature review analysis is accomplished relating to the alternativeness of aortic valve (AoV) repairs in children of various ages with AoV disease. Long- and midterm results of AoV repairs in children both with severe aortic regurgitation and aortic stenosis are outlined. Several advantages and feasibility of AoV repairs over aortic valve replacement accentuating on the individualization of surgical repair strategy to the age of the patient, durability of the repair depending on material properties, growth potential and geometry of AoV are substantiated.
\end{abstract}

Key words: aortic valve repair, children, reoperation.

Recently, there have been a number of publications describing advance repair techniques for congenital AoV pathology, especially bicuspid AoVs in adults and this has renewed the interest in pursuing valve repair in children [1, 2]. Ideally, aortic valve repair would relieve the hemodynamic burden on the left ventricle (LV), permit growth, avoid valve replacement and the need for anticoagulation.

Objectives. To scrutinize the latter data, reports regarding to various reconstructive $\mathrm{AoV}$ repair and highlight the optimization of the surgical option of repair types in children of diverse age groups.

In adults, successful AoV repair commonly includes techniques borrowed from the valve sparing root experience including the use of prosthetic grafts to wrap the root and support the annulus. There are two important weaknesses in adopting the adult experience in AoV repair in children. First, extensive external annular support in small children would prevent growth. Second and the most importantly, the age at presentation is a marker of severity and the pathology in adults is far less severe than in children. Even in adults, one could question whether $\mathrm{AoV}$ replacement is replaceable for a durable AoV repair. A recent study of AoV repairs from the Cleveland Clinic demonstrated a 10 -year freedom from reoperation of less than $80 \%$ in patients with a mean age of $42 \pm 12$ years [2].

Are aortic stenosis and aortic regurgitation equal with their post-repair prognosis? Surgery for congenital aortic stenosis in children generally involves commissurotomy plus thinning of the adherent fibrous tissue on the leaflets. These repairs are durable and show reoperation free survival in excess of $85 \%$ at 10 years [3,4]. Durable relief of regurgitation on the other hand, is a far greater challenge and here the results in children are uniformly poor with less than $50 \%$ freedom of reoperation at 8 years in several single institution series $[3,5,6]$. A number of techniques have been applied including leaflet suspension, restructuring and augmentation of the commissures with pericardium and leaflet extensions.

AoV repairs' shortcomings and their predisposing factors. Despite the ability to achieve excellent immediate outcomes the repairs lack durability and within too short a time, regurgitation recurs. This likely represents a problem with both our techniques and materials. Repairs for regurgitation require extensive use of additional materials either xenograft patches or fixed autologous pericardium. In addition, suture lines are required to flex repeatedly and repair forces are commonly concentrated into a small regions, resulting in structural failure. These materials are subject to rapid degeneration due to fibrosis with retraction and calcification. In primary repairs with a usage of treated autologous pericardium reoperation shows 2 main mechanisms of failure: restrictive motion leading to late reoperation and excessive motion leading to early reoperation. Though experience and reports in the literature have accumulated, the debate on the optimal material is still ongoing, especially given the disparity of data (children and adults mixed), the small number of pediatric patients and the new materials.

On top of aforementioned factors that patient growth has a major impact on repair durability. The growth potential of the AoV complex can be considered in 2 directions: vertical (from cusp nadir to Arantius nodula) and horizontal (intercommissural). Regarding to growth of the AoV and patients' ages, the whole repair procedures are subdivided in 2 variations:

- Unrestrictive procedures (commissurotomy shaving or neocommissure creation) maintain growth potentials in both directions.

- Restrictive procedures (leaflet replacement and extension) restrain intercommissural growth. 
A restrictive procedure in small children (especially under the age of 1 year) leads to a reoperation sooner rather than later. In young patients ( $<10$ years), neocommissure creation is promising; 2 other techniques (commissurotomy shaving or leaflet replacement) are equally effective. In older patients ( $>10$ years), all techniques except leaflet extension offered $80 \%$ freedom from reoperation at 8 years of followup [7].

One justification cited by the Vergnat and colleagues for use of AoV repair is the ability to delay AoV replacement to an older age. Unfortunately, the paper by Vergnat et al. [7] does not separate the outcomes based on the physiologic indication for surgery. Stenosis as the primary indication was present in about $2 / 3$ of the patients. The results show a $80 \%$ freedom of reoperation at 8 years of follow-up, entirely consistent with the previous studies cited above. The end point in the study by Vergnat et al. is freedom from reoperation. While this end point is widely accepted, reoperation is a measure of physician behaviour and is not always a reflection of the physiologic burden on the LV, that is, recurrent stenosis or regurgitation impacting on the success of repair. Although efforts should be oriented to maintain the native valve in younger children as long as possible, preservation of LV function is also critical to this strategy. Indeed, LV failure is consistently associated with death in the Ross procedure [8] and may lead to earlier AoV replacement [9]. For some authors, AoV repair may prolong LV exposure to pressure or volume overload and thus jeopardize future outcome for these patients [10]. Thus, preserving the native valve as long as possible, without affecting LV function, leaves all other options still valid without limitations (supported Ross/mechanical valve and even recurrent repair).

As previously identified [11], valve morphology influenced outcomes, with tricuspid morphology providing a protective effect against reoperation and, more importantly, against replacement. This effect may be due either to the underlying morphology, to a better geometrical configuration favouring durability or to the maintenance of the further possibility of re-repair (leaflet rereplacement instead of valve replacement).

Current and further perspective visions with respect to AoV repair.

If AoV repair in children is to become a real therapeutic option, better material and techniques will be required. Recently, the technique of valve repair developed by Ozaki et al. [12] has been adapted to children. This involves 3 leaflet replacement with bioprosthetic tissue. The suture line forces are distributed over a much a larger area, and the new leaflets have a large area of coaptation, further relieving stress on the repair. In addition, a more uniform repair technique amenable to a variety of anatomic situations may simplify our approach and achieve consistent results. One persistent weakness is the use of devitalized pericardium that will predictably degenerate in children. Perhaps nonbioprosthetic material may be considered such as $0.1 \mathrm{~mm}$ polytetrafluoroethylene. While it will not grow, it is not subject to degeneration or neointimal ingrowth and could prove to be more durable.

AoV replacement with a pulmonary autograft, the Ross procedure, is widely used in children and is the valve replacement option of choice. The results of the Ross procedure in children are excellent. The German Dutch Ross registry shows a 10-year freedom of reoperation in excess of $90 \%$, far superior to any report on AoV repair for aortic regurgitation in children [13]. Excellent results have been achieved even in infants. In the case of the Ross procedure, there seems to be little justification for an arbitrary age cut-off. In addition, there is a growing body of evidence in the paediatric field that dilatation and failure of neoaorta occur in up to $40 \%$ of patients in the second decade [14] and $28 \%$ at median follow-up duration of 5.2 years after Ross procedure [15].

Finally, in children mechanical valves provide excellent freedom from reoperation although clearly the potential need for annular enlargement and the requirement of lifelong anticoagulation remain as shortcomings [16].

\section{Conclusion}

1. Commissurotomy with thinning appeared to be approved as regards aortic stenosis underlining its durability and real-world applicability.

2. Allowing the patient to grow to an age when more definitive solutions are available, surgical AoV repair strategy should be individualized to the age of the patient.

3. Despite the criticisms noted above, valve repair can achieve intermediate results without affecting LV function that may be a reasonable alternative to valve replacement in neonates and infants without an autograft option, especially if the alternative is prosthetic valve replacement that requires extensive annular enlargement. Ultimately, valve repair should reduce the use of replacement procedures in the growing child.

4. Future work in this area should be directed to developing more consistent techniques and better materials that will result in more durable repairs.

\section{References}

1. Valvesparing root reimplantation and leaflet repair in a bicuspid aortic valve: comparison with the 3-cusp David procedure / Bavaria J. E., Desai N., Szeto W. Y. et al. // J Thorac Cardiovasc Surg. - 2015. - Vol. 149. - 2 P. 2-8.

2. Long-term durability of bicuspid aortic valve repair / Svensson L. G., Al Kindi A. H., Vivacqua A. et al. // Ann Thorac Surg. - 2014. - Vol. 97. - P. 1539-47; discussion 48.

3. Complex aortic valve repair as a durable and effective alternative to valve replacement in children with aortic valve disease / Tweddell J. S., Pelech A. N., Frommelt P. C. et al. // J Thorac Cardiovasc Surg. - 2005. - Vol. 129. P. 551-8.

4. The long-term outcome of open valvotomy for critical aortic stenosis in neonates / Hraska V., Sinzobahamvya N., 
Haun C. et al. // Ann Thorac Surg. - 2012. - Vol. 94. P. 1519-26.

5. Baird C. W., Myers P. O., del Nido P. J. Aortic valve reconstruction in the young infants and children // Semin Thorac Cardiovasc Surg Pediatr Card Surg Annu. - 2012. Vol. 15. - P. 9-19.

6. Outcomes after operations for bicuspid aortic valve disease in the pediatric population / Siddiqui J., Brizard C. P., Konstantinov I. E. et al. // Ann Thorac Surg. - 2013. Vol. 96. - P. 2175-83.

7. Contemporary results of aortic valve repair for congenital disease: lessons for management and staged strategy / Vergnat M., Asfour B., Arenz C. et al. // Eur J Cardiothorac Surg. - 2017. - Vol. 52. - P. 581-7.

8. Mitral disease: the real burden for Ross-Konno procedure in children / Vergnat M., Roubertie F., Lambert V. et al. // AnnThorac Surg. - 2014. - Vol. 98. - P. 2165-71.

9. The influence of valve physiology on outcome following aortic valvotomy for congenital bicuspid valve in children: 30-year results from a single institution / Karamlou T., Shen I., Alsoufia B. et al. // Eur J Cardiothorac Surg. 2005. - Vol. 27. - P. 81-5.

10. Karl T. R. Left ventricular outflow tract obstruction: justification for a more definitive repair in the neonate? // Eur J Cardiothorac Surg. - 2012. - Vol. 42. - P. 694-5.
11. Surgical aortic valvotomy in infancy: impact of leaflet morphology on long-term outcomes / Bhabra M. S., Dhillon R., Bhudia S. et al. // Ann Thorac Surg. - 2003. Vol. 76.- P. 1412-6.

12. A total of 404 cases of aortic valve reconstruction with glutaraldehydetreated autologous pericardium / Ozaki S., Kawase I., Yamashita H. et al. // J Thorac Cardiovasc Surg. - 2014. - Vol. 147. - P. 301-6.

13. Reoperations on the pulmonary autograft and pulmonary homograft after the Ross procedure: An update on the German Dutch Ross Registry / Charitos E. I., Takkenberg J. J., Hanke T. et al. // J Thorac Cardiovasc Surg. - 2012. - Vol. 144. - P. 813-21; discussion 21-3.

14. Longterm survival and reintervention after the ross procedure across the pediatric age spectrum / Nelson J. S., Pasquali S. K., Pratt C. N. et al. // Ann Thorac Surg. 2015. - Vol. 99. - P. 2086-94.

15. Hitendu D, Christoph M, Rene $\mathrm{P}$ et al. Dilatation and dysfunction of the neo-aortic root and in 76 patients after the Ross procedure / Corina A. Z., Roland W., Matthias G. et al. // Pediatr Cardiol. - 2016. - Vol. 37. - P. 1175-1183.

16. Intermediate-term results after the aortic valve replacement using bileaflet mechanical prosthetic valve in children / Masuda M., Kado H., Ando Y. et al. // Eur J Cardiothorac Surg. - 2008.- Vol. 34. - P. 42-7.

\title{
Чи є пластика аортального клапана розумною альтернативою протезування для дітей?
}

\author{
Абдурахманов 3. М., Варбанець С.В., Ємець І. М. \\ ДУ «Науково-практичний медичний центр дитячої кардіології та кардіохірургії МОЗ України» (Київ)
}

Проведено аналіз огляду літератури, пов’язаний з альтернативністю пластики аортального клапана стосовно протезування у дітей різного віку з вадами аортального клапана. Описано віддалені та середньовіддалені результати пластики аортального клапана у дітей із вираженою аортальною регургітацією та аортальним стенозом. Обгрунтовано переваги реконструктивних операцій на аортальному клапані, основну увагу приділено індивідуалізації вибору виду хірургічної пластики у дітей різних вікових груп, надійності пластики залежно від властивостей матеріалу, потенціалу росту та геометрії аортального клапана.

Ключові слова: пластика аортального клапана, діти, повторна операція. 